\title{
The Bargaining Power in Taiwan Interbank Overnight Market
}

\author{
Mei-Yin Lin ${ }^{1}$, Hanyu $\mathrm{Hsu}^{2} \&$ Jue-Shyan Wang ${ }^{2}$ \\ ${ }^{1}$ Department of Economics, Shih Hsin University, Taiwan \\ ${ }^{2}$ Department of Public Finance, National Chengchi University, Taiwan \\ Correspondence: Mei-Yin Lin, Associate Professor, Department of Economics, Shih Hsin University, Taiwan. \\ E-mail:mylin@cc.shu.edu.tw
}

Received: June 18, 2013

Accepted: July 22, 2013

Online Published: August 26, 2013

doi:10.5539/ijef.v5n9p50

URL: http://dx.doi.org/10.5539/ijef.v5n9p50

\begin{abstract}
The rate corridor regime, relying on lending and deposit facilities to set ceilings and floors for interbank overnight rates, has been practiced by many central banks. This paper modifies the theoretical model proposed by Bech and Klee (2011) to discuss the seller's bargaining power in Taiwan interbank overnight market under rate corridor system. We apply two-limit Tobit model to estimate the bargaining power. The empirical results show that the repo rate, policy indicator and index for reserves concentration have significantly positive relationship with seller's bargaining power. Meanwhile, the results imply that the interbank overnight rates rise with these three variables. The conclusions could be clearly observed from the predictions on the paths of the interbank overnight rate under various scenarios.
\end{abstract}

Keywords: interbank overnight market, bargaining power, Tobit Model

\section{Introduction}

The operating procedures of monetary policy involve instruments (tools), operating targets, intermediate targets, and policy goals. Central Banks manipulate the instruments to achieve a specified value of an operating target. In recent years, the interest rate on interbank overnight loans has been widely used as the primary operating target for monetary policy because it is the most immediate source of regulating banks' liquidity. For example, the Fed has announced a federal funds rate target at each Federal Open Market Committee meeting since February 1994. The European Central Bank sets a target for the overnight cash rate which is similar to the federal funds rate. Therefore, the whole market participants keep close watch on the announcement of the interbank overnight rate because it affects interest rates throughout the economy.

The central banks can use their monopoly power over the supply of currency and reserves to influence the interbank overnight rate. The basic reserves market model could be used to examine the responses of the reserves quantities and interbank overnight rate under alternative instruments. Much literature discusses a rate corridor regime for interbank overnight market which has been practiced in Australia, New Zealand, Sweden and Switzerland. Some features of this regime have been described in Whitesell (2006) and Mishkin (2013). Operationally, the discount rate is set at a premium above the target rate, while the interest rate paid on the reserve balances (deposit rate) is set at a spread below the target rate. The discount rate functions as a ceiling and the deposit rate as a floor for the interbank overnight rate. As the reserve demand fluctuates, the interbank overnight rate will stay between these two limits.

The financial crisis of 2007-2009 led the Fed to adopt the corridor system. The authority to pay interest rate on reserve balances had been granted by Congress in 2006 but was not effective until October 2011. The financial crisis induced the Fed to implement this power on October 6, 2008. However, the effective federal funds rate did not stay above the floor of the corridor. Lavoie (2010) explains this phenomenon by the fact that not all the participants in the federal funds are eligible to receive interest payments on their reserve balances. The government-sponsored enterprises (GSEs) and foreign institutions get nothing on their reserve balances. This creates a segmented market where these institutions lack bargaining power and are being forced to lend at a rate below the floor. Moreover, Bech and Klee (2011) develop a bargaining model to explore the behavior of the federal funds rate. They use information on observed rates to calibrate the bargaining power of the different participants. The theoretical model proposed by Bech and Klee would provide us an available framework to analyze Taiwan interbank overnight market. 
Taiwan interbank overnight market, as called interbank call loans market, was established in April 1980. Originally, the participants were restricted to those institutions, like the domestic banks and local branch of foreign banks, which were required to hold reserve balances. To expand the size of transactions, investment and trust companies (ITC) and bills finance companies (BFC) that were not required to hold reserve balances had been allowed to join the interbank overnight market since 1991. Figure 1 shows the transactions by institutions. The domestic banks are the most important traders in the market. ITC and BFC seem to usually stand in the position of borrowing. However, the amount of transactions by ITC and BFC is not large.

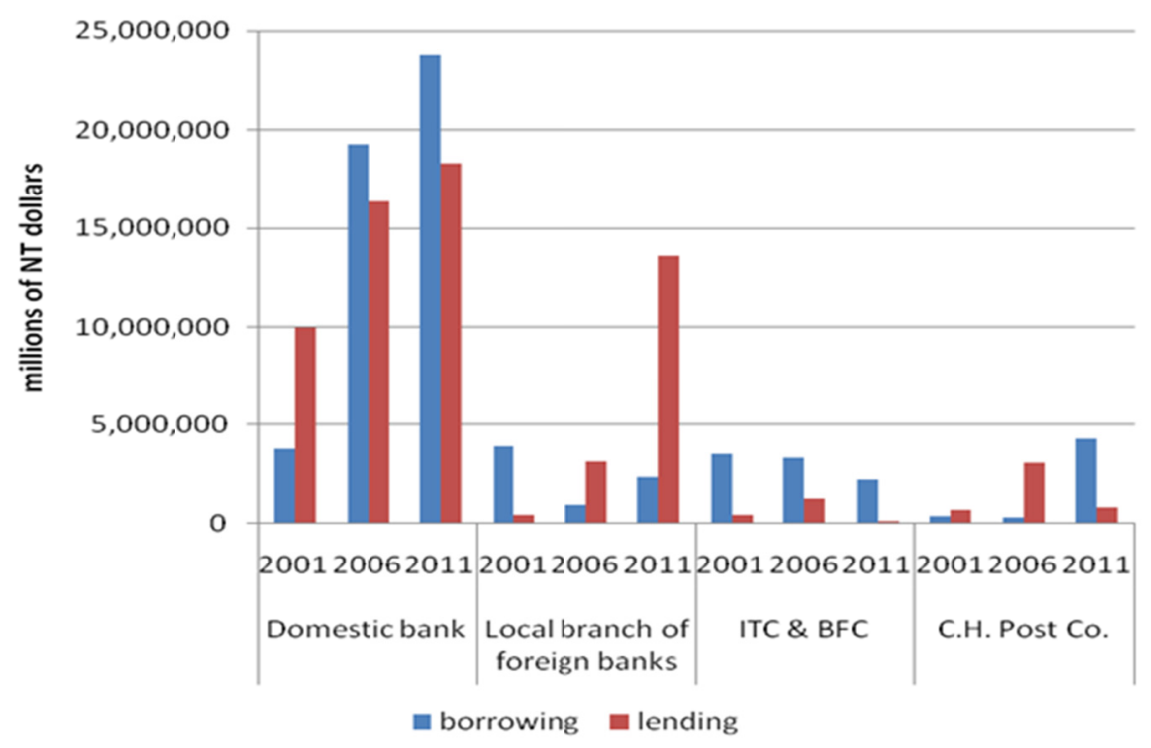

Figure 1. Interbank overnight transactions by institutions

Source: Central Bank of R.O.C (Taiwan), Financial Statistics Monthly.

As most other countries, banks in Taiwan could borrow at the discount window offered by the central bank or get the liquidity from other banks. However, the central bank of Taiwan set the discount rate as the floor of the target rate before 2003. To be correspondent with the corridor scheme of other countries, the interbank overnight rate has been allowed to be lower than the discount rate since 2003. This feature is illustrated in Figure 2 . Additionally, the interbank overnight rate does not really stay within the corridor.

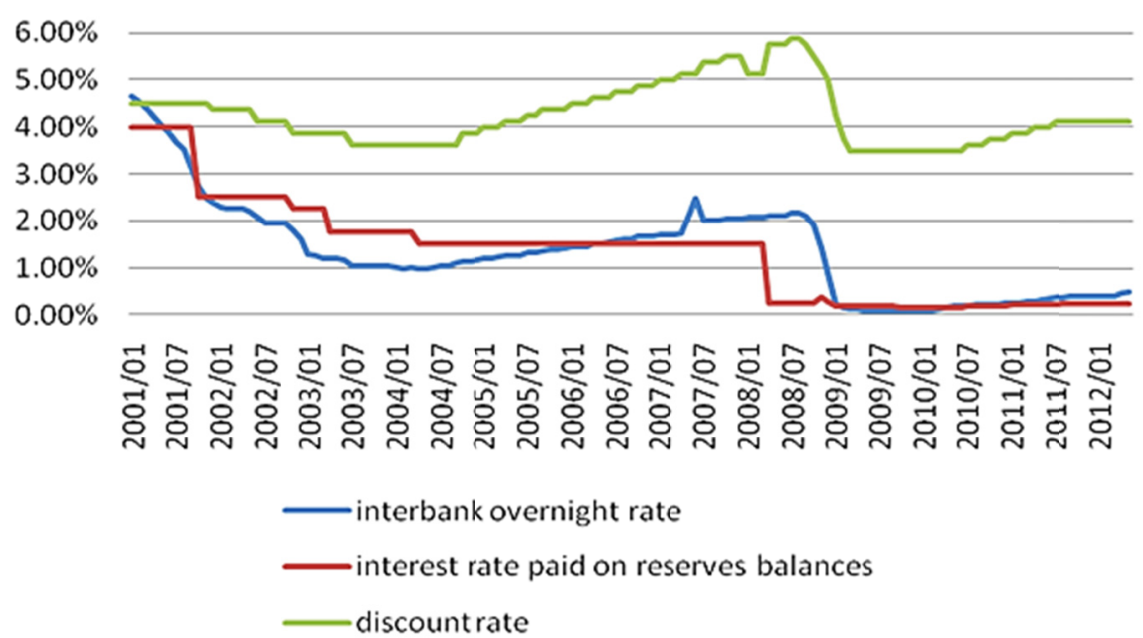

Figure 2. Taiwan interbank overnight rates 
Bech and Klee (2011) propose a model with heterogeneous participants in markets and banking. However, the roles of ITC and BFC in Taiwan are not as significant as that of GSEs in the United States. Therefore, this paper will not deal with the problem of heterogeneity in the theoretical model. Instead, we use the share variables in the econometric model to investigate the influence of ITC and BFC on the bargaining power in Taiwan interbank overnight market. This paper is organized as follows. We describe the bargaining model and its implications in Section 2. Then we will calibrate the model to Taiwan interbank overnight market data and back out the bargaining power of the market participants in Section 3. We also predict the interbank overnight rate under various scenarios in this section. The conclusions are in Section 4.

\section{The Model}

\subsection{Theoretical Model}

The economy consists a central bank and a set of profit-maximizing and risk-neutral agents that buy and sell overnight funds in the interbank overnight market. According to the definition of Nash, a bargaining problem with two agents could be expressed as a pair $(F, d)$, where $F$ is the set of feasible agreements, and $d$ indicates the threat point. Bech and Klee define a bargaining model where the utility of the agents is equal to the interest income. Following the argument of Binmore et al. (1986), the Nash solution could be written as

$$
r^{*}(F, d)=\underset{d \leq f}{\arg \max }\left(f^{\text {buyer }}-d^{\text {buyer }}\right)^{1-\beta}\left(f^{\text {seller }}-d^{\text {seller }}\right)^{\beta}
$$

where $r^{*}$ is the equilibrium interbank overnight rate in this bargaining model, $\left(f^{\text {buyer }}, f^{\text {eller }}\right)$ denote the interest rate paid by the buyer (borrower) and the interest rate received by the seller (lender) respectively, and $\left(d^{\text {buyer }}, d^{\text {seller }}\right)$ indicate the highest rate at which the buyer is willing to borrow money and the lowest interest at which the seller is willing to lend fund. Moreover, $\beta \in[0,1]$ is the bargaining power of the seller, and then $1-\beta$ is the bargaining power of the buyer. The final solution implies that the buyer pays the seller the interest $r$. It means that $\left(f^{\text {buyer }}\right.$, $\left.f^{\text {eller }}\right)=(-r, r)$. The threat point should satisfy the conditions that $d^{\text {buyer }} \leq f^{\text {buyer }}=-r$ and $d^{\text {seller }} \leq f^{\text {eller }}=r$. The Nash solution in equation (1) could be rewritten as

$$
r^{*}=\underset{d^{\text {seller }} \leq r \leq-d^{\text {byyer }}}{\arg \max }\left(-r-d^{\text {buyer }}\right)^{1-\beta}\left(r-d^{\text {seller }}\right)^{\beta}
$$

Setting the first-order condition of equation (2) being zero yields the solution of $r$ as

$$
r^{*}=d^{\text {seller }}+\beta\left(-d^{\text {buyer }}-d^{\text {seller }}\right)=-d^{\text {buyer }}-(1-\beta)\left(-d^{\text {buyer }}-d^{\text {seller }}\right)
$$

In the model of Bech and Klee, there are two segmented markets and the effective federal funds rate is the weighted average rate yielding from the bargaining problem in each market. However, the separation of Taiwan interbank overnight market is not significant because of the little amount of transactions by ITC or BFC. Therefore, we will directly use equation (3) to discuss the behavior of Taiwan interbank overnight rate.

Suppose the interest rate paid on reserve balances is $r_{\text {ioer }}$, it is clear that the seller will not lend to other bank if the interbank overnight rate is lower than $r_{i o e r}$. It implies that $d^{\text {seller }}=r_{\text {ioer }}$. Let $r_{\text {sdw }}$ denote the discount rate, and it is known the buyer will not borrow money from other bank if the interbank overnight rate is higher than $r_{s d w}$. It means that $d^{\text {buyer }}=-r_{s d w}$. The surplus can be divided between two parties is the interest rate difference $r_{s d w}-r_{i o e r}$. Therefore equation (3) can be expressed as

$$
r^{*}=r_{\text {ioer }}+\beta\left(r_{\text {sdw }}-r_{\text {ioer }}\right)=r_{\text {sdw }}-(1-\beta)\left(r_{\text {sdw }}-r_{\text {ioer }}\right),
$$

We discuss the implications derived from equation (4). First, an increase in the seller's bargaining power $(\beta)$ will raise the interbank overnight rate. It implies the seller could ask for a higher interest payment if his bargaining power increases. The positive relationship will be magnified when the surplus that could be divided between two parties is larger. This property is observed by differentiating equation (4) with respect to $\beta$.

$$
\partial r^{*} / \partial \beta=r_{s d w}-r_{i o e r} \geq 0
$$

Secondly, we analyze the impact of interest rate paid on reserve balances by the following differentiating equation.

$$
\partial r^{*} / \partial r_{\text {ioer }}=1-\beta \geq 0
$$

The interbank overnight rate moves in the same direction with the interest rate paid on reserve balances. 
Intuitively, an increase in the interest rate paid on reserve balances will raise the threat point of the seller. Thus the buyer should pay more interest to get the fund. Moreover, the magnitude of this positive relationship depends on the size of borrower's bargaining power.

Finally, an increase in the discount rate will make the interbank overnight rate be higher. The reason is that the demand for interbank loan will increase when the cost of alternative source of fund (discount window) is higher. Then it pushes up the interbank overnight rate. The extent of this positive relationship is relevant to the seller's bargaining power and could be shown by the following equation.

$$
\partial r^{*} / \partial r_{s d w}=\beta \geq 0
$$

\subsection{Econometric Model}

By rearranging equation (4), the seller's bargaining power could be expressed as

$$
\hat{\beta}=\frac{r^{*}-r_{i o e r}}{r_{s d w}-r_{i o e r}}
$$

Because the interbank overnight rate has been allowed to be lower than the discount rate since 2003, we will use the interest rate data available by the Central Bank of R.O.C. (Taiwan) to construct the values of seller's bargaining power $(\beta)$ for Taiwan from January 2003 to May 2012. The time series is shown in Figure 3. Obviously, the values of seller's bargaining power $(\beta)$ do not stay between zero and one at all times. We will focus on those observations that the values of seller's bargaining power keep within the reasonable ranges. Instead of the fractional response model used by Bech and Klee, we will apply Tobit model to investigate the behavior of bargaining power in Taiwan interbank overnight market.

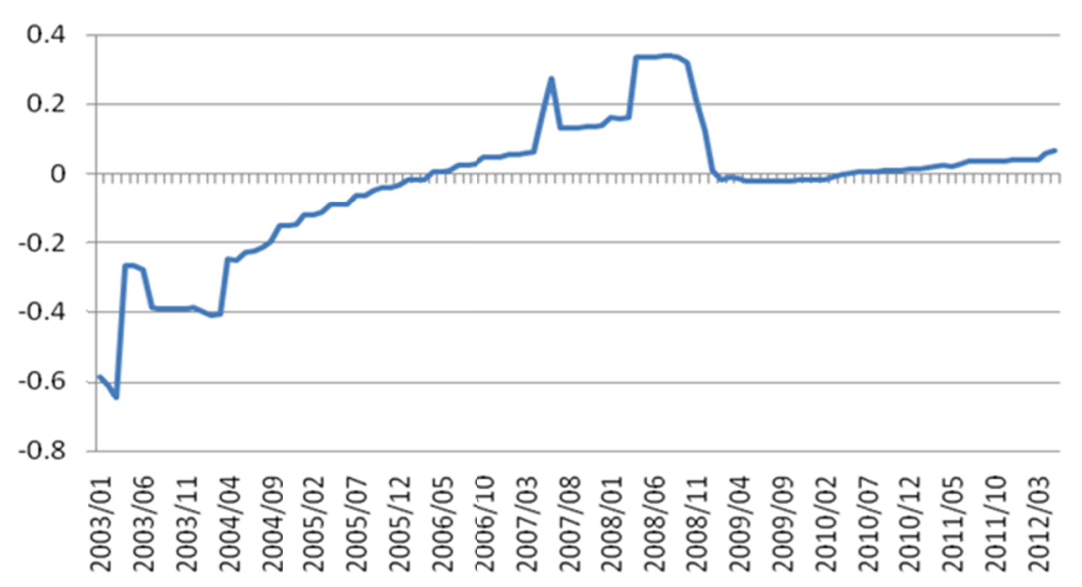

Figure 3. Seller's bargaining power $(\beta)$

We consider a regression model in which the dependent variable is continuous and recorded in only some of the ranges. The two-limit Tobit model provides a framework for us to estimate the bargaining power when it will be truncated at both high and low values. The model is defined as follows:

$$
\beta_{t}^{*}=\gamma^{\prime} \mathbf{x}_{\mathbf{t}}+u_{t}
$$

where $\beta_{t}^{*}$ is the latent variable, $\gamma$ is a $k \times 1$ vector of parameters, $\mathrm{x}$ is a $k \times 1$ vector of explanatory variables, and $u_{t}$ are disturbances that are independently and normally distributed, with mean zero and a common variance $\sigma^{2}$. Let the seller's bargaining power $\left(\beta_{t}\right)$ be the observed dependent variable,

$$
\beta_{t}=\left\{\begin{array}{ccc}
0 & \text { if } & \beta_{t}^{*} \leq 0 \\
\beta_{t}^{*} & \text { if } & 0<\beta_{t}^{*}<1 \\
1 & \text { if } & \beta_{t}^{*} \geq 1
\end{array}\right.
$$

The likelihood function is given by 


$$
L\left(\gamma, \sigma \mid \beta_{t}, \mathbf{x}_{t}\right)=\prod_{\beta_{t}=0} \Psi\left(\frac{-\gamma^{\prime} \mathbf{x}_{\mathbf{t}}}{\sigma}\right) \prod_{\beta_{t}=\beta_{t}^{*}} \Psi\left(\frac{\beta_{t}-\gamma^{\prime} \mathbf{x}_{\mathbf{t}}}{\sigma}\right) \prod_{\beta_{t}=1}\left[1-\Psi\left(\frac{1-\gamma^{\prime} \mathbf{x}_{\mathbf{t}}}{\sigma}\right)\right]
$$

Two-stage estimation procedure could be used to obtain the maximum-likelihood estimates of $\boldsymbol{\gamma}$ and $\sigma^{2}$. The more detail discussion about this model could be seen in Maddala (1983).

\section{Empirical Results}

\subsection{Determinants of Bargaining Power}

Basing on the settings of Bech and Klee, we specify six variables that may be the important factors in determining the bargaining power. The first variable, Balances, denotes the logarithm of total level of reserve balances held by the financial institutions. The higher level of reserve balances implies there is not much demand for reserves. It is expected to reduce the seller's bargaining power.

The second variable, $\boldsymbol{H H I}$, indicates the Herfindahl-Hirschman index which measures the concentration of the reserve balances. This index is computed as the square sum of reserve share for the largest 29 financial institutions in Taiwan. Intuitively, if the reserves are held by a few participants (a higher HHI), the structure of the market is near monopoly. It will strengthen the seller's bargaining power.

The third variable, $\boldsymbol{R e p o}$, is the repurchase agreement rate on government bonds secondary market (1-30 days). It is known the repo market and the interbank overnight market are substitutes. A higher repo rate provides the seller with alternative investment opportunity. It increases the seller's bargaining power.

The forth variable, $\boldsymbol{N P L}$, is the non-performing loans ratio of all financial institutions. It measures the health state of the banking sector. Increases in counterparty risk will lead to worse information asymmetry. Moreover, banks are not willing to lend because they prefer to keep liquidity for precautionary reasons. For example, Afonso et al. (2011) suggest the importance of liquidity hoarding and counterparty risk in the U.S. interbank overnight market during financial crisis of 2008. Thus a higher non-performing loans ratio reduces interbank lending and the seller's bargaining power might be lower.

The fifth variable, Policy, describes the monetary policy environment. We set a dummy variable that equals 1 if the rate paid on reserve balances changes at the later month. The expectation about future monetary policy will affect the motive for bank to hold reserves.

The sixth variable is not included in the study of Bech and Klee. We consider the ratios of the amount of borrowing (lending ) by BFC and ITC to total borrowing (lending) which are denoted by $\boldsymbol{B F C}^{\boldsymbol{b}}\left(\boldsymbol{B F} \boldsymbol{C}^{\boldsymbol{}}\right)$ and $\boldsymbol{I T C}^{\boldsymbol{b}}$ $(\boldsymbol{I T C})$, respectively. These share variables capture the influence of those heterogeneous participants over the bargaining power.

The data set is obtained from the Central Bank of R.O.C (Taiwan), Financial Statistics Monthly, and the databank provided by Taiwan Economic Journal (TEJ). The sample period ranges from January 2003 to May 2012, with a total 111 monthly observations. The descriptive statistics for the variables involved in this study are presented in Table 1.

Table 1. Descriptive statistics

\begin{tabular}{ccccc}
\hline Variable & Mean & Std. Dev. & Maximum & Minimum \\
\hline Balances & 6.0737 & 0.0766 & 6.1900 & 5.9400 \\
HHI & 0.1523 & 0.0582 & 0.2586 & 0.0231 \\
Repo & 0.0095 & 0.0056 & 0.0211 & 0.0013 \\
NPL & 2.4274 & 1.7428 & 6.8400 & 0.4200 \\
Policy & 0.1171 & 0.3230 & 1.0000 & 0.0000 \\
BFC $\boldsymbol{b}^{\boldsymbol{b}}$ & 0.0010 & 0.0018 & 0.0064 & 0.0000 \\
$\boldsymbol{B F C}_{\boldsymbol{I T C}}^{\boldsymbol{b}}$ & 0.0082 & 0.0010 & 0.0381 & 0.0000 \\
$\boldsymbol{I T C}^{\boldsymbol{T}}$ & 0.1413 & 0.0763 & 0.3432 & 0.0433 \\
\hline
\end{tabular}

\subsection{Empirical Results}

We use two-limit Tobit model described in equation (8) and (9) to estimate the seller's bargaining power. The independent variables include the factors mentioned in section 3.1. We exclude the influence of heterogeneous participants in Model 1. Then add the share variables relevant to the transaction of BFC and ITC in Model 2, 3, 4. 
The empirical results are presented in Table 2. Repo and Policy are two significant variables that are positively related to seller's bargaining power. A higher repo rate tends to push up seller's bargaining power as expected. Bech and Klee find the same evidence for GSEs that are significant sellers in Federal Funds market. Moreover, anticipation of the change in rate paid on reserve balances will stimulate the seller's bargaining power. The concentration index $(\boldsymbol{H H I})$ is positively related to seller's bargaining power. It is consistent with our expectation. The total level of reserve balances (Balances) and the health state of the banking sector (NPL) do not significantly determine bargaining power except in Model 1 . The coefficient on NPL is insignificantly negative. We explain this result with two effects. The first effect is noted previously that counterparty risk makes seller reduce lending and it raises seller's bargaining power. The second effect is that the injection of liquidity by central bank in the worse financial state causes the decrease in seller's bargaining power. These two effects move in the opposite directions and then the total effect is indefinite.

The coefficients on lending share of BFC are significant negative in Model 2 and Model 4. In addition, the influence of ITC is insignificant. BFC need not hold reserves and they lend fund under consideration of benefit. If BFC participate the selling market more aggressively, it will reduce the other seller's bargaining power. By contrast, this effect does not be found when BFC act as borrowers in the market. It is worth noting that BFC, like other banks, could borrow at the discount window offered by the central bank. Therefore, the borrowing decisions for BFC are similar to other banks.

Table 2. Estimation for seller's bargaining power with two-limit Tobit Model

Dependent variable: seller's bargaining power

\begin{tabular}{|c|c|c|c|c|}
\hline Independent variables & Model 1 & Model 2 & Model 3 & Model 4 \\
\hline Balances & $\begin{array}{l}0.9172 \\
(1.72)^{*}\end{array}$ & $\begin{array}{c}0.3869 \\
(0.83)\end{array}$ & $\begin{array}{c}0.3331 \\
(0.54)\end{array}$ & $\begin{array}{l}0.2767 \\
(0.49)\end{array}$ \\
\hline HHI & $\begin{array}{c}0.2514 \\
(0.60)\end{array}$ & $\begin{array}{l}0.7357 \\
(2.01)^{* *}\end{array}$ & $\begin{array}{l}0.5412 \\
(1.32)^{*}\end{array}$ & $\begin{array}{l}0.7628 \\
(2.05)^{* *}\end{array}$ \\
\hline Repo & $\begin{array}{l}28.4326 \\
(9.70)^{* * *}\end{array}$ & $\begin{array}{l}26.3012 \\
(10.32)^{* * *}\end{array}$ & $\begin{array}{c}31.0454 \\
(10.50)^{* * *}\end{array}$ & $\begin{array}{l}27.3549 \\
(9.46)^{* * *}\end{array}$ \\
\hline$N P L$ & $\begin{array}{l}-0.0715 \\
(-1.71)^{*}\end{array}$ & $\begin{array}{c}-0.0534 \\
(-1.54)\end{array}$ & $\begin{array}{c}-0.0667 \\
(-1.47)\end{array}$ & $\begin{array}{c}-0.0505 \\
(-1.28)\end{array}$ \\
\hline Policy & $\begin{array}{l}0.0700 \\
(2.94)^{* * *}\end{array}$ & $\begin{array}{l}0.0446 \\
(2.16)^{* *}\end{array}$ & $\begin{array}{c}0.0606 \\
(2.62)^{* * *}\end{array}$ & $\begin{array}{l}0.0449 \\
(2.13)^{* *}\end{array}$ \\
\hline$B F C^{b}$ & & $\begin{array}{c}-35.7521 \\
(-0.25)\end{array}$ & & $\begin{array}{c}-80.4513 \\
(-0.52)\end{array}$ \\
\hline$B F C$ & & $\begin{array}{l}-5.8211 \\
(-4.11)^{* * *}\end{array}$ & & $\begin{array}{l}-4.9660 \\
(-2.75)^{* * *}\end{array}$ \\
\hline$I T C^{b}$ & & & $\begin{array}{c}-0.1960 \\
(-0.71)\end{array}$ & $\begin{array}{c}-0.1155 \\
(-0.45)\end{array}$ \\
\hline$I T C$ & & & $\begin{array}{l}-3.2061 \\
(-2.27)^{* *}\end{array}$ & $\begin{array}{c}-0.9999 \\
(-0.63)\end{array}$ \\
\hline Constant & $\begin{array}{l}-5.7982 \\
(-1.75)^{*}\end{array}$ & $\begin{array}{c}-2.6094 \\
(-0.90)\end{array}$ & $\begin{array}{c}-2.2349 \\
(-0.59)\end{array}$ & $\begin{array}{c}-1.9292 \\
(-0.56)\end{array}$ \\
\hline Log likelihood & 74.3070 & 81.7969 & 77.4090 & 82.1069 \\
\hline
\end{tabular}

Notes: $t$ values are given in parentheses. ${ }^{* * *},{ }^{* * *}$, indicate significance at $1 \%, 5 \%, 10 \%$ statistical level, espectively.

\subsection{Prediction of Interbank Overnight Rate}

Central bank can change the interest rate paid on reserve balances to alter the rate corridor. In this section, we intend to predict the interbank overnight rate under different setting for interest rate paid on reserve balances. From Table 2, the log likelihood ratio for Model 4 is the highest among all models. Therefore, we apply the coefficients estimated by Model 4 to perform this predicting exercise. All the independent variables involved in the regression are assumed to stay in their mean level as shown in Table 1 . The discount rate is set at mean level (4.25\%). Especially, we plot the implied interbank overnight rate with different assumptions for BFC lending share. In the low (high) scenario, the BFC lending share is assumed to be the average level minus (plus) one standard deviation.

Figure 3 illustrates the fact that higher interbank overnight rates are associated with higher interest rates 
paid on reserve balances. Moreover, a higher BFC lending share results in a lower interbank overnight rate because it implies a lower seller's bargaining power. A further point to be noted is that the interbank overnight rates with different assumptions for BFC lending share will converge to the same level as the interest rate paid on reserve balances increases.

Figure 4 to Figure 6 show the effects of different level of total reserve balances, different degree of index of reserve concentration and different value of repo rate on the interbank overnight rate, respectively. The positively sloped paths suggest that the interbank overnight rates rise with these three variables. The negative relationship between non-performing loans ratio and interbank overnight rate is observed in Figure 7.

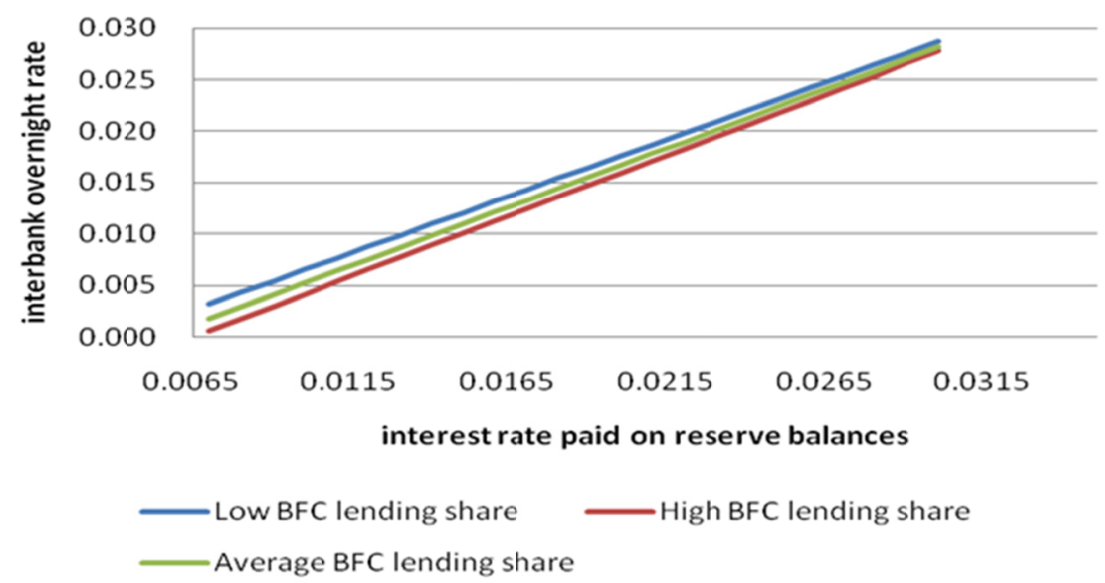

Figure 3. Prediction of interbank overnight rate—by interest rate paid on reserve balances

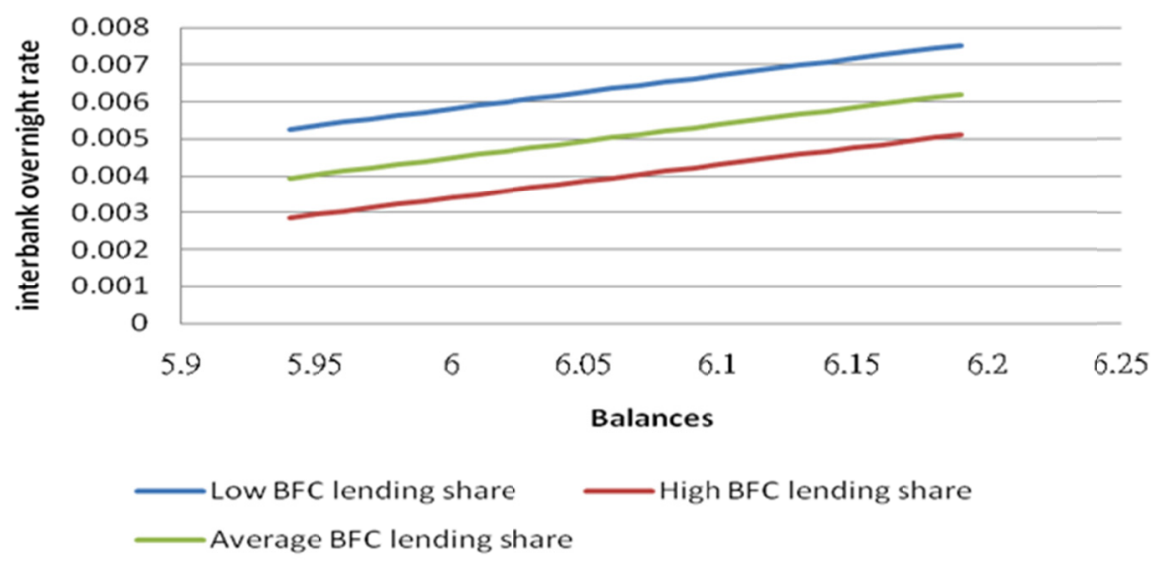

Figure 4. Prediction of interbank overnight rate—-by total level of reserve balances 


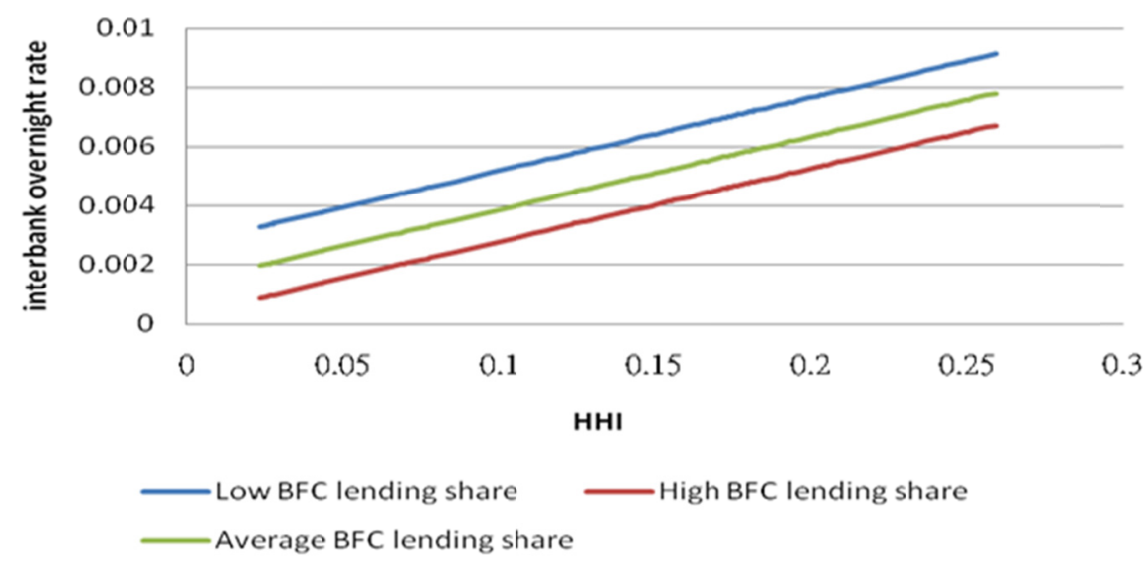

Figure 5. Prediction of interbank overnight rate - by index of reserves concentration

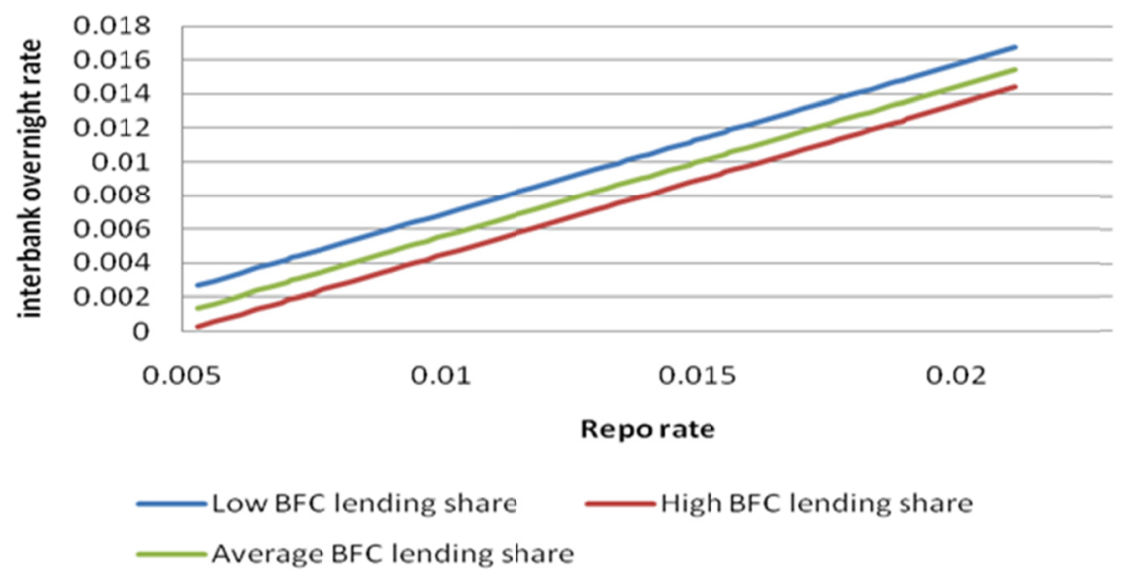

Figure 6. Prediction of interbank overnight rate—-by repo rate

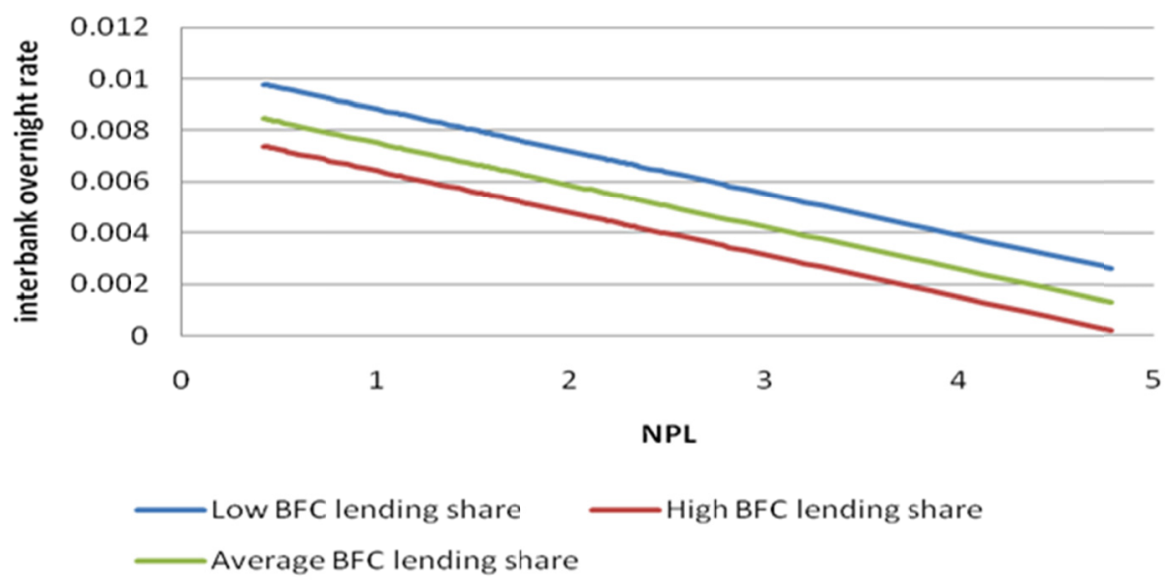

Figure 7. Prediction of interbank overnight rate — by non-performing loans ratio

\section{Conclusions}

This paper modifies the theoretical model proposed by Bech and Klee to investigate the seller's bargaining power in Taiwan interbank overnight market under rate corridor system. We apply two-limit Tobit model to estimate the bargaining power and evaluate the impacts on interbank overnight rate under various scenarios. The empirical results show that the repo rate, policy indicator and index for reserves concentration have 
significantly positive relationship with seller's bargaining power. Meanwhile, the results also imply that the interbank overnight rates rise with these three variables. The predictions on the paths of the interbank overnight rate under different scenarios make our conclusions more clear.

This issue could be extended to focus on other Asian countries where central banks play important roles in stabilizing the financial system. Especially, it is interesting to investigate the dynamics of interbank overnight rates during financial crisis. Because the manipulations of reserves schemes are different among Asian countries, the theoretical model used in this paper could be modified to fit each economy. It may help us to look more closely at the behavior of central banks.

\section{References}

Afonso, G., Kovner, A., \& Schoar, A. (2011). Stressed, not frozen: The federal funds market in the financial crisis. Journal of Finance, 66, 1109-1139. http://dx.doi.org/10.1111/j.1540-6261.2011.01670.x

Bech, M. L., \& Klee, E. (2011). The mechanics of a graceful exit: Interest on reserves and segmentation in the federal funds market. Journal of Monetary Economics, 58, 415-431. http://dx.doi.org.autorpa.lib.nccu.edu.tw/10.1016/j.jmoneco.2011.05.007

Binmore, K., Rubinstein, A., \& Wolinsky, A. (1986). The nash bargaining solution in economic modeling. Rand Journal of Economics, 17, 176-188. http://dx.doi.org/10.2307/2555382

Lavoie, M. (2010). Changes in central bank procedures during the subprime crisis and their repercussions on monetary theory. International Journal of Political Economy, 39, 3-23. http://dx.doi.org/10.2753/IJP0891-1916390301

Maddala, G. S. (1983). Limited-dependent and qualitative variables in econometrics. Cambridge University Press. http://dx.doi.org/10.1017/CBO9780511810176

Mishkin, F. S. (2013). The Economics of Money, Banking, and Financial Markets (10th ed.). Pearson Education, Inc.

Whitesell, W. (2006). Interest rate corridors and reserves. Journal of Monetary Economics, 53, 1177-1195. http://dx.doi.org/10.1016/j.jmoneco.2005.03.013

\section{Copyrights}

Copyright for this article is retained by the author(s), with first publication rights granted to the journal.

This is an open-access article distributed under the terms and conditions of the Creative Commons Attribution license (http://creativecommons.org/licenses/by/3.0/). 